\title{
PEMBERDAYAAN EKONOMI JAMA'AH MASJID MELALUI KOPERASI
}

\author{
Oleh: \\ Muhammad Endy Fadlullah \& M. Amir Mahmud \\ Institut Agama Islam Ibrahimy Genteng Banyuwangi \\ amir_klby@yahoo.co.id \& mefadlullah@yahoo.com
}

\begin{abstract}
:
This writing discusses about the way of devotion in Mosque Nurul Hidayah Sarimulyo Village Cluring of Banyuwangi. Action of Emphasis devotion is empowerment programmer, implementation of empowerment programmer and result of empowerment program to pilgrim of Nurul Hidayah Mosque. The empowerment is part of participation devotion which put community position as perpetrators of social change has hope by them. The effort will be achieved on two stages for four months and be start from on September until on December 2016. Some cycles are part of empowerment strategic which will do in this devotion. Results of devotion are 1) Form empowerments pilgrim in Mosque are enhancement economic programmer such as training and establishment of cooperation. 2) Implementations of empowerment pilgrim mosque as training and establishment are smoothly. It was formed stewardship and membership on business field such as provision of basic foods, snacks, books of Qiroati, electrical token listrik, PLN and others. But some of them did not yet done because of limited of modal and time. 3) Results of empowerment pilgrim mosque can dug, push and give motivation and make pilgrims independent and confidence.
\end{abstract}

Key Word: pemberdayaaan ekonomi, jamaah masjid, koperasi

\section{A. Pendahuluan}

Kondisi perekonomian global saat ini masih berada pada fase yang penuh ketidakpastian, antara lain ditunjukkan oleh koreksi proyeksi pertumbuhan perekomian dunia oleh lembaga-lembaga internasional. Belum kondusifnya perkembangan perekonomian di dunia antara lain diakibatkan oleh melemahnya pertumbuhan ekonomi negara-negara maju dan berkembang, penurunan harga komoditas, serta perbedaan arah kebijakan moneter dan fiskal di berbagai kawasan (Kemenkeu, 2015).

Adanya dinamika perekonomian global yang senantiasa berubah seharusnya ummat Islam mampu beradaptasi dan bersaing disegala bidang kehidupan. Hal ini karena didalam Islam sendiri sebenarnya sudah terdapat petunjuk-petunjuk arahan-arahan baik di dalam alqur'an dan al

$$
\begin{array}{l|l}
\text { JURNAL LISAN AL-HAL } & 361
\end{array}
$$


hadis maupun ijtihad para ulama' yang dapat dijadikan pedoman bagi umat Islam. Hal ini dapat dilihat bagaimana konsep zakat, puasa, sodaqoh jariyah yang diarahkan kepada kesejahteraan kaum miskin.

Namun faktanya ummat Islam masih belum sepenuhnya mampu bersaing. Indonesia sebagai negara dengan jumlah penduduk muslim terbesar di dunia menerima dampak perekonomian global tersebut. Di Indonesia jumlah penduduk miskin pada Maret berjumlah 2016 28,01 juta orang. Separuh lebih dari penduduk miskin tersebut merupakan umat Islam, dengan asumsi bahwa 89 persen penduduk di Indonesia adalah muslim.

Masih banyaknya penduduk muslim yang berada dibawah garis kemiskinan membuktikan bahwa belum terlaksananya ajaran Islam secara utuh. Masjid sebagai "icon" ummat Islam masih belum difungsikan secara maksimal. Selama ini masjid hanya sebagai pusat peribadatan umat Islam dalam bentuk ibadah sholat fardu 5 waktu, sholat jum'at atau sholat-sholat sunnah seperti sholat hari raya, sholat tarawih dan sholat-sholat sunnah yang lain. Kegiatan lain yang biasanya dilaksanakan di masjid untuk berdzikir, beristighosah, bersholawat, TPQ, pengajian dan memperingati hari-hari besar Islam. Sayangnya kegiatan yang terkait dengan pendidikan, sosial dan ekonomi jarang sekali dilakukan. Perhatian utama dari jamaah masjid saat ini dan menjadi trend adalah menjadikan masjid memiliki bangunan yang megah dan indah. Hal ini dapat dibuktikan dengan hasil riset Kemenag menunjukkan bahwa $89,9 \%$ dari 800 ribuan masjid se Indonesia saat ini sepi dari kegiatan keagamaan. Sementara itu hasil survey menunjukkan bahwa jumlah masjid di Indonesia diperkirakan mencapai 800.000 masjid. Sementara itu jumlah masjid seluruh Indonesia yang di bawah jaringan Lembaga Ta'mir Masjid Indonesia-Nahdlatul Ulama' (LTMI-NU) hingga sekarang mencapai 125.000 masjid, namun hanya ada beberapa masjid yang telah memfungsikan masjid sebagai pemberdaya umat $^{1}$. Perkara-perkara yang sangat esensial seperti kemiskinan yang menimpa jamaahnya tidak mendapat perhatian sama sekali. Hal ini lebih disebabkan karena keterbatasan cara pandang terhadap peran dan fungsi masjid.

Jika bercermin dari apa yang dicontohkan oleh baginda Nabi Muhammad SAW, peran masjid tidak hanya sebagai tempat untuk shalat berjamaah, peran masjid memiliki arti yang sangat luas. Masjid dijadikan sebagai pusat pembinaan dan kegiatan ummat. Pada masa itu masjid dijadikan sebagai tempat latihan perang, tempat pengobatan bagi tentara-

${ }^{1}$ https://mtsfalakhiyah.wordpress.com/2011/01/07/

$362 \mid$ JURNAL LISAN AL-HAL 
tentara muslim, pengadilan, tempat menuntut ilmu, pusat dakwah, tempat pembinaan ummat, tempat kaderisasi umat Islam dan kebudayaan.

Kondisi Masjid di seluruh nusantara pada umumnya mengalami kondisi yang sama seperti di atas, hal ini tidak jauh berbeda dengan Masjid Nurul Hidayah yang berada di Desa Sarimulyo Kecamatan Cluring Kabupaten Banyuwangi. Sekarang ini, Masjid mengalami kelesuan dalam kegiatan keagamaan, pendidikan bahkan sosial. Hal ini dapat dilihat dari kegiatan rutinitas yang dilakukan oleh ketakmiran yang hanya cenderung dengan kegiatan-kegiatan vertikal. Kelesuan kegiatan di berbagai lini elemen jamaah tentu sangat memprihatinkan jika terus berlanjut. Perlu upaya yang jitu dan strategis untuk segera mengatasi kelesuan tersebut. Jika kondisi ini terus terjadi bukan tidak mungkin degradasi moral masyarakat akan semakin terbentang dihadapkan kita. Mengembalikan fungsi masjid sebagai benteng moral dan spiritual masyarakat tentu sebuah keharusan. Namun dalam kondisi kehidupan masyarakat dewasa ini harus ada upaya cerdas, cerdik, dan cermat dalam memberdayakan masjid sekaligus memberdayakan jamaahnya.

Untuk menjawab permasalahan khususnya yang terjadi di masjid Nurul Hidayah dengan melihat potensi-potensi yang ada baik sumber daya alam maupun sumber daya manusia yang dimilikinya maka program pengabdian ini ingin mengoptimalkan pemberdayaan yang diarahkan kepada peningkatan perekonomian jamaah masjid. Dengan pemberdayaan ini diharapkan kegiatan sosial ekonomi berjalan dengan baik, jamaah terikat dengan masjid, perekonomian jamaah masjid meningkat khususnya warga miskin dan masjid menjadi sentra kegiatan jamaah diberbagai bidang kehidupan. Adapun tujuan pengabdian ini adalah sebagai berikut: 1) Untuk mengetahui bentuk program pemberdayaan jamaah di masjid Nurul Hidayah; 2) Untuk mengetahui pelaksanaan program pemberdayaan jamaah di masjid Nurul Hidayah; dan 3) Untuk mengetahui hasil dari program pemberdayaan jamaah di masjid Nurul Hidayah.

Upaya pemberdayaan ekonomi umat berbasis masjid ini merupakan bagian dari kegiatan sosial keagamaan yang diharapkan mampu menstimulasi berbagai bentuk kesadaran dan tindakan para jamaah masjid. Sehingga pada proses dampingan dan pasca dampingan program pemberdayaan ini harapannya adalah;

1) Masjid menjadi pusat kegiatan masyarakat (jamaah) seperti kegiatan ibadah, pendidikan, sosial dan ekonomi. Kondisi ini akan berimplikasi pada kesadaran warga bahwa masjid tidak hanya memiliki fungsi 
penjaga nilai keagamaan namun juga penjaga kelangsungan hidup warga.

2) Masyarakat memiliki kekuatan kemampuan dalam menganalisis permasalahan yang mereka hadapi, membuat rencana dan pemecahan masalahnya sehingga dengan kekuatannya sendiri mampu mengupayakan pembangunan untuk dirinya sendiri yang berkelanjutan dalam bidang sosial, ekonomi dan lingkungan secara mandiri.

\section{B. Strategi Pelaksanaan}

Upaya pemberdayaan ini merupakan bagian dari pengabdian partisipasi yang lebih memposisikan masyarakat sebagai bagian dari pelaku perubahan sosial yang diharapkan. Pengabdi sebagai fasilitator masyarakat memiliki peran dalam mengembangkan pembelajaran masyarakat untuk membangun kemandirian dalam menyelesaikan masalah yang mereka hadapi, membangun kesadaran kritis masyarakat terhadap berbagai masalah ekonomi yang sedang berlangsung disamping itu memperkuat kemampuan masyarakat untuk berdialog sehingga memiliki bargaining position yang kuat dengan kekuatan lain.

Upaya tersebut akan dicapai dalam dua tahapan yang berlangsung selama empat bulan yang dimulai bulan September-Desember 2016. Siklus ini sekaligus merupakan bagian dari strategi pemberdayaan yang akan dilakukan dalam pengabdian ini.

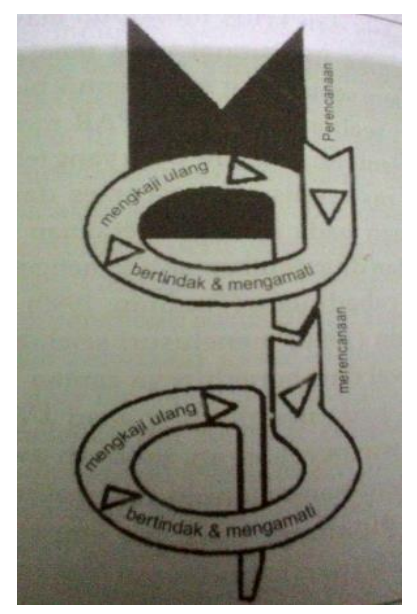

Gambar 1. Sipral Penelitian Tindakan (Denzin, N.K \& Lincoln, Y.S, 2009)

364 JURNAL LISAN AL-HAL 
Sebelum di lakukan siklus pertama, pengabdi mengadakan assesement awal untuk melihat kondisi senyatanya, melakukan investigasi, dan pemetaan. Upaya ini dilakukan untuk menguatkan strategi yang telah pengabdi susun.

Sesuai dengan Spiral Penelitian Tindakan, tahap pertama yang dilakukan adalah melakukan penggalian masalah yang melibatkan masyarakat, pengabdi sebagai fasilitator yang membantu masyarakat menemukan dan merumuskan permasalahan mereka serta mencari solusi jalan keluar atas permasalahan tersebut. Hal ini dilakukan melalui FGD (Focus Group Discussion) yang melibatkan berbagai pihak terkait (Stakeholder). Langkah selanjutnya adalah membuat rencana strategi kegiatan atas permasalahan yang dihadapi oleh masyarakat tersebut. Berikutnya adalah aksi atau tindakan dari rencana yang telah dibuat dan tahap terakhir adalah evaluasi program serta refleksi. Hasil dari evaluasi dan refleksi pada tahap/siklus pertama menjadi patokan untuk masuk kedalam siklus/tahap kedua yang juga memiliki tahapan perencanaan, aksi, evaluasi dan refleksi. Tehnik evaluasi program yang telah dilaksanakan menggunakan alat analisis LFA (Logical Framework Approach).

\section{Gambaran Umum Lokasi Pengabdian}

Masjid Nurul Hidayah merupakan salah satu masjid yang terletak di Dusun Sempu Desa Sarimulyo Kecamatan Cluring Kabupaten Banyuwangi dan dibangun diatas tanah wakaf pada tahun 1980. Memiliki luas $1000 \mathrm{~m}^{2}$. Di sebelah timur masjid terdapat halaman rumput dengan luas $40 \mathrm{~m} \times 30$ $m$, di timur masjid juga terdapat bangunan Pondok Pesantren dan bangunan sekolah Taman Kanak Kanak / Ruodlotul Atfal (TK/RA) yang menghadap ke selatan, bangunan Pondok pesantren di sebelah timur yang menghadap ke barat serta bangunan kantor remaja masjid yang berada di sebelah selatan menghadap ke keselatan atau arah jalan. Tanah Wakaf Masjid Nurul Hidayah merupakan hasil pemberian dari tiga orang dermawan yang sekaligus menjadi tokoh agama di daerah ini, mereka itu adalah KH Abdul Wahab, KH. Abdus Somad dan Mbah Tohirah yang ketiganya ini masih saudara.

Jarak antara masjid Nurul Hidayah dengan jalan raya propinsi sekitar $100 \mathrm{~m}$ dan jarak tempuh masjid ke kota Banyuwangi kurang lebih $30 \mathrm{~km}$. Secara administratif batas desa Sarimulyo di sebelah barat adalah desa Tamanagung kecamatan Cluring, sebelah timur berbatasan dengan Desa Tapanrejo Kecamatan Muncar, sebelah utara berbatasan dengan Desa Kebaman Kecamatan Srono dan sebelah selatan berbatasan dengan 
Desa Sraten Kecamatan Cluring.

Masjid Nurul Hidayah merupakan masjid yang menerapkan sistem amaliah ala Ahlussunnah wal jamaah an nahdliyah memiliki jumlah jamaah kurang lebih 200 jamaah yakni jamaah laki-laki sebanyak 100 orang dan jamaah perempuan sebanyak 100 orang. Awal masjid itu didirikan oleh masyarakat telah digunakan untuk kegiatan rutinitas sholat berjamaah dan sholat jum'at dan mengaji al qur'an setelah maghrib. Lambat laun kegiatan masjid mulai mengalami kemajuan yang cukup pesat pada tahun 1990-2000 berbagai kegiatan keagamaan juga mewarnai seperti Madrasah Diniyah, qira'ah, khithabiyah, barzanji, Yasinan, Tahlilan, kesenian Hadrah "Jedoran", dan olahraga bela diri Pagar Nusa. Kegiatan ke-remajaan masjid dalam kurun waktu 1990 hingga akhir tahun 2000-an berjalan sangat meriah. Berbagai kegiatan keagamaan dan peringatan hari besar Islam (PHBI) seperti takbir keliling, peringatan Maulid Nabi, Rajabiyah, Isra' Mi'raj, peringatan tahun baru Islam dengan menghadirkan dai-dai kondang seperti Roma Irama, Kirun, KH. Zainuddin MZ, Nur Muhammad Iskandar dan lain-lain yang sebagian besar digerakkan oleh remaja masjid. Di samping itu pula diskusi-diskusi mengenai keagamaan, keorganisasian, bahaya narkoba, pendidikan seks juga sering dilakukan. Di kalangan jamaah tua, berbagai kegiatan juga pernah mewarnai, seperti dzikir fida', khotmil qur'an, dan lain-lain.

Namun setelah tahun 2000-an kegiatan jamaah terus menurun hingga saat ini, masjid hanya berfungsi sebagai tempat jamaah sholat fardu, sholat Jum'at dan sholat Idh. Bahkan saat ini, kegiatan sholat fardu 5 waktu hanya diisi oleh jamaah kalangan tua, itu pun dengan jumlah yang sedikit, tidak lebih dari 15 orang setiap harinya. Sedangkan berbagai kegiatan keagamaan yang pernah ada berkurang drastis. Para santri pondok pesantren yang datang dari berbagai penjuru di Indonesia yang juga ikut meramaikan masjid telah habis tidak tersisa satupun, madrasah diniyah dari kalangan remaja masjid juga turut habis. Dari hasil wawancara yang dilakukan kepada jamah atau warga sekitar masjid Nurul Hidayah dapat ditemukan beberapa penyebab terjadinya kemunduran dan kevakuman kegiatan masjid Nurul Hidayah ini. Pertama, ada yang mengatakan hal ini terjadi karena tokoh agama yang menjadi Kyai masjid dan sekaligus pondok pesantren tersebut terlibat aktif di sebuah organisasi politik. Kedua, masyarakat secara umum dalam hak berpolitik mempunyai pilihan yang berbeda dengan Kyai mereka, sehingga sering terjadi ketidak cocokan antara jamaah masjid dengan Kyai merena yang berdampak terhadap berkurangnya rasa kepercayaan jamaah terhadap Kyai, hal ini berimbas kepada kemalasan warga untuk melakukan kegiatan 
di masjid. Ketiga, ustadz-ustadzahnya sibuk bergelut dengan ekonominya baik bekerja sebagai buruh tani maupun menjadi kuli bangunan, sehingga tidak bisa maksimal dalam memberi pengajaran terhadap anak-anak yang ingin mengaji. Selain itu pula, beberapa ustadz terpaksa pergi ke luar daerah dan luar negeri untuk mencari penghidupan yan lebih layak, bekerja dan keluar daerah untuk kepentingan ekonomi. Keempat, ketidak cocokan antara kalangan orang tua dengan kalangan remaja, sehingga berakibat pada kemalasan dan ketidak pedulian kalangan remaja untuk mengadakan kegiatan di masjid. Kelima, dominasi orang tua yang kurang memberikan ruang gerak kepada kalangan muda, sehingga regenerasi mengalami kebuntuan, remaja menjadi terpencar-pencar, demikian juga anak menjadi terlantar. Hanya kegiatan Dzikiran tiap malam Senin yang masih berjalan itupun diisi kalangan tua.

Sebenarnya para pengurus masjid mempunyai cita-cita yang mulia yaitu ingin meramaikan (memakmurkan) masjid dengan mengadakan kegiatan seperti dzikir bersama setiap malam senin, membuat pendidikan formal PAUD dengan menggaji guru secara gratis, pendidikan TPQ, dan pembangunan renovasi masjid dan membuat gedung baru. Solusinya adalah ta'mir menggali dana dengan cara mencari donatur dan meminta sumbangan kepada para jamaah. Pengambilan dana donatur dilakukan dengan cara ketua ta'mir sendiri langsung mendatangi donatur. Para donatur berfariatif dalam memberikan sumbangan ada yang menyumbang dua puluh lima ribu, lima puluh ribu dan seratus ribu perbulannya. Akan tetapi setelah berjalan kurang lebih lima bulan semangat ketua ta'mir dalam mengambil sumbangan mulai menurun, terkadang datang ke donatur dan terkadang tidak, dan akhirnya tidak sama sekali sampai saat ini. Menurunnya semangat ketua ta'mir ini dipicu oleh beberapa faktor seperti bertambahnya umur ketua ta'mir dan disibukkan dengan pekerjaan dan urusan keluarga.

Masjid Nurul Hidayah memiliki potensi sumber daya manusia, yakni adanya Kyai masjid dengan keilmuan agama yang bagus, beberapa tokoh agama, pengusaha-pengusaha sukses, pegawai negeri-pegawai negeri, petani-petani kaya. Selain itu, masjid Nurul Hidayah juga memiliki sumber daya lingkungan yang sangat strategis untuk di kembangkan seperti lokasi yang cukup luas dengan luas tanah wakaf sekitar masjid kurang lebih 1hektar, terdapat bangunan-bangunan pondok pesantren tanpa penghuni, dan terdapat beberapa gedung kosong, cocok untuk kegiatan perekonomian, dekat dengan jalan raya $(50 \mathrm{~m}$ dari jalan Propinsi) dekat dengan Perguruan Tinggi dan Sekolah-sekolah.

Jika dilihat secara umum, kondisi ekonomi jamaah masjid Nurul

\begin{tabular}{l|l} 
JURNAL LISAN AL-HAL & 367
\end{tabular} 
Hidayah saat ini bervariasi. Sebagian besar bermata pencarian sebagai petani, baik petani palawija, sayur mayur maupun petani jeruk. Sebagian lain bekerja sebagai pedagang dan sebagian kecil sebagai PNS dan bekerja serabutan. Bagi jamaah yang bekerja menanam palawija dan sayur-mayur hasil panennya cukup dibuat memenuhi kebutuhan sehari-hari sehingga jika dilihat tingkat ekonominya/kesejahteraannya tergolong miskin. Begitu halnya dengan jamaah yang bekerja serabutan. Hanya petani yang memiliki lahan luas, pedagang besar dan PNS lah yang kehidupannya terlihat mapan. Ketidak merataan ekonomi juga dapat dilihat dari tempat tinggalnya. Bagi jamaah yang hidup miskin terlihat sekali rumah mereka sangat tidak layak bahkan mendekati roboh hal ini sangat kontras dengan jamaah yang ekonominya sudah mapan. Jamaah ini memiliki rumahrumah yang besar, kendaraan angkut (dumtruck) lebih dari 5, kendaraan pribadi, memiliki gudang yang luas, sawah yang luas. Perbedaan ini dapat memunculkan kecemburuan sosial jika tidak diimbangi dengan memunculkan rasa empati dan simpati terhadap jamaah lain yang kurang beruntung

\section{Pelaksanaan Pengabdian}

Pada program pengabdian ini kami menggunakan metode PAR (Parsipatory Action Research) yang melibatkan partisipasi dari masyarakat jamaah masjid dalam proses pemberdayaannya. Pada dasarnya PAR melibatkan pihak-pihak terkait (stakeholder) dalam mengkaji persoalan yang mereka hadapi dan dalam rangka melakukan perubahan dan perbaikan kearah yang lebih baik. Yang mendasari digunakan PAR adalah kebutuhan untuk mendapatkan perubahan yang diinginkan. Sebelum menjalankan metode PAR terlebih dahulu kami melakukan Riset Pendahuluan. Riset pendahuluan dilakukan sebagai cara untuk mendalami subyek pengabdian. Riset pendahuluan dilakukan dengan cara mengamati atau observasi langsung kehidupan sehari-hari para jamaah masjid Nurul Hidayah. Observasi dilakukan dengan meninjau tempat tinggal, kegiatan sehari-hari (kegiatan dirumah dan di masjid) dan pekerjaan jamaah. Riset pendahuluan juga dilakukan dengan melakukan pendataan ekonomi jamaah masjid sehingga dengan demikian Pengabdi bisa mengamati permasalahan yang mereka hadapi.

Hasil pemetaan dan pendataan yang telah dilakukan terhadap jamaah masjid Nurul Hidayah diketahui bahwa dari 60 kepala keluarga jamaah masjid didapatkan keluarga dengan status sejahtera III plus sebanyak 10\%, sejahtera III 48,3\%, sejahtera II 20\%, sejahtera I 11,7\% dan prasejahtera 10\% (Gambar 1). Ada sebagian dari keluarga sejahtera 
III ini yang anggota keluarganya rata-rata sudah berusia lanjut dan di tinggal anaknya merantau keluar daerah. Jika dilihat dari segi lahiriah kehidupan mereka tercukupi baik untuk makan sehari-hari, tempat tinggal, kesehatan tetapi jika sebenarnya mereka merasa kesepian dan merasa kurang bahagia dikarenakan hanya tinggal bersama istrinya yang juga berusia lanjut. Kriteria keluarga sejahtera dapat dilihat pada Lampiran 1.
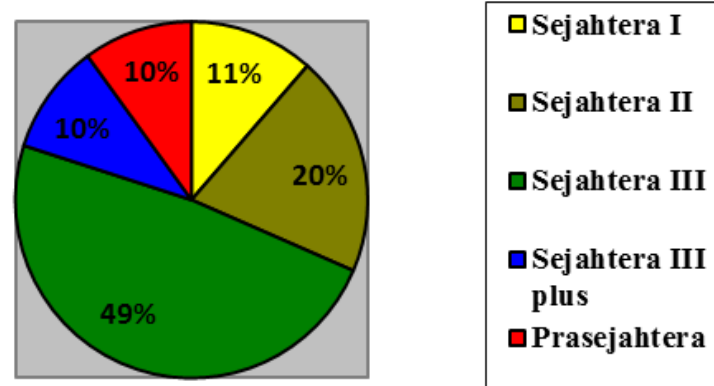

Gambar 2. Grafik ekonomi keluarga jamaah Masjid Nurul Hidayah

Selain kategori III terdapat warga yang dikategorikan sebagai keluarga sejahera II yakni sudah terpenuhi kebutuhan sehari-harinya seperti makanan dan pakaian. Mereka dapat makan 2-3 kali sehari dan juga dapat memakai pakaian yang berbeda antara pakaian di rumah dan ketika kegiatan ke luar. Namun meskipun mereka tergolong sejahtera sebagian ada yang memiliki riwayat penyakit kronis seperti stroke dan diabetes.

Selanjutnya keluarga sejahtera 1 berjumlah 8 KK artinya mereka ini sudah bisa memenuhi kebutuhan sehari-harinya. Untuk makan, pakaian, kesehatan sudah terpenuhi mungkin hanya kekurangan satu dari hal-hal tersebut tapi pada hakikatnya mereka hidup sudah lebih mapan dari pada keluarga yang prasejahtera. Terdapat 6 kepala keluarga yang berada pada kriteria prasejahtera dan mayoritas dari mereka adalah ibu-ibu janda yang sudah lanjut usia dan sebagiannya lagi sebagai pemulung sampah. Denah hasil pemetaan ekonomi keluarga jamaah Masjid Nurul Hidayah dapat dilihat pada Gambar 3 


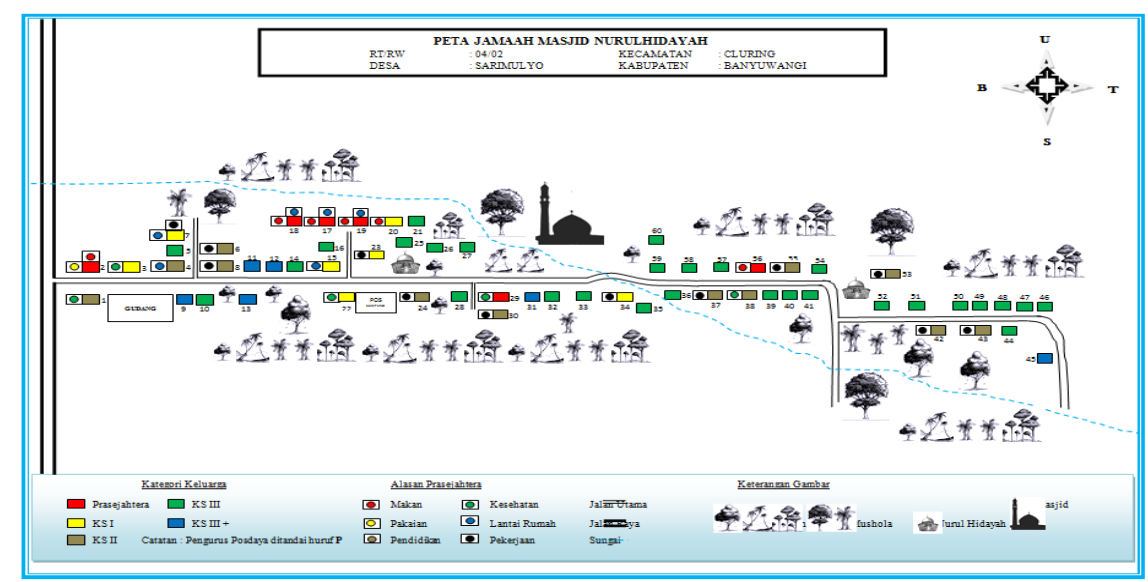

Gambar 3. Denah pemetaan ekonomi jamaah Masjid Nurul Hidayah

Riset pendahuluan ini menjadi pijakan untuk analisis selanjutnya yaitu inkulturasi. Pada tahap inkulturasi ini pengabdi membaur dalam masyarakat dengan cara ikut serta dalam kehidupan keseharian mereka seperti shalat berjamaah. Data awal tentang jamaah masjid menjadi dasar dalam berbaur dengan jamaah. Pengabdi juga melakukan pendekatan terhadap masyarakat dengan cara mengikuti berbagai kegiatan keagamaan yang masyarakat/jamaah rutin lakukan seperti majlis dzikir al-kawakib, majlis istighosah malam senin, majlis taklim malam selasa, dan majlis yasin.

\section{E. Pengorganisasian Masyarakat untuk Agenda Pengabdian}

Pembentukan kelompok masyarakat/jamaah masjid dipilih dari beberapa anggota jamaah yang tergolong solid yaitu baik berasal dari golongan sejahtera III PLUS, III, II, I dan prasejahtera. Untuk golongan prasejahtera semuanya direkrut menjadi anggota kelompok karena golongan ini nanti yang diutamakan perubahannya. Tujuan membentuk kelompok ini adalah untuk meningkatkan kebersamaan dengan upaya untuk memperkuat kepercayaan diri, tanggung jawab dan memunculkan rasa empati diantara anggota kelompok. Tahapan pra-pengabdian diatas setelah selesai dilaksanakan maka selanjutnya adalah pelaksanaan metode PAR. Sesuai dengan langkah kegiatan yang dilakukan meliputi:

\section{Siklus pertama}

Pada siklus pertama ini dilakukan kegiatan perencanaan, aksi, evaluasi, dan refleksi. Perencanaan, pada bagian ini diadakan pertemuan 
kelompok antara jamaah masjid yang telah terbentuk dan dilaksanakan pada tanggal 10 September 2016. Dalam pertemuan ini dilakukan FGD (Focus Group Discussion) yaitu diskusi mengenai permasalahan tertentu yang telah disepakati sebelumnya. FGD dihadiri oleh stakeholder seperti ketua Rt, ketua Rw, Kepala Dusun, Kyai dan tokoh masyarakat serta anggota jamaah masjid. Dalam FGD anggota kelompok diajak untuk menganalisis dan merumuskan masalah. Para anggota kelompok diajak untuk mengkaji permasalahannya serta mencari solusinya. Hasil dari kegiatan pemetaan ekonomi jamaah yang telah dilakukan oleh pengabdi sebelumnya menjadi bahan untuk FGD. Adanya diskusi ini diharapkan jamaah masjid menjadi terbuka wawasan, kesadaran dan pemahamannya mengenai kondisi ekonomi warga disekitar masjid. Perumusan masalah dilakukan dengan tehnik analisis pohon masalah sebagaimana ditunjukkan pada Gambar 4.

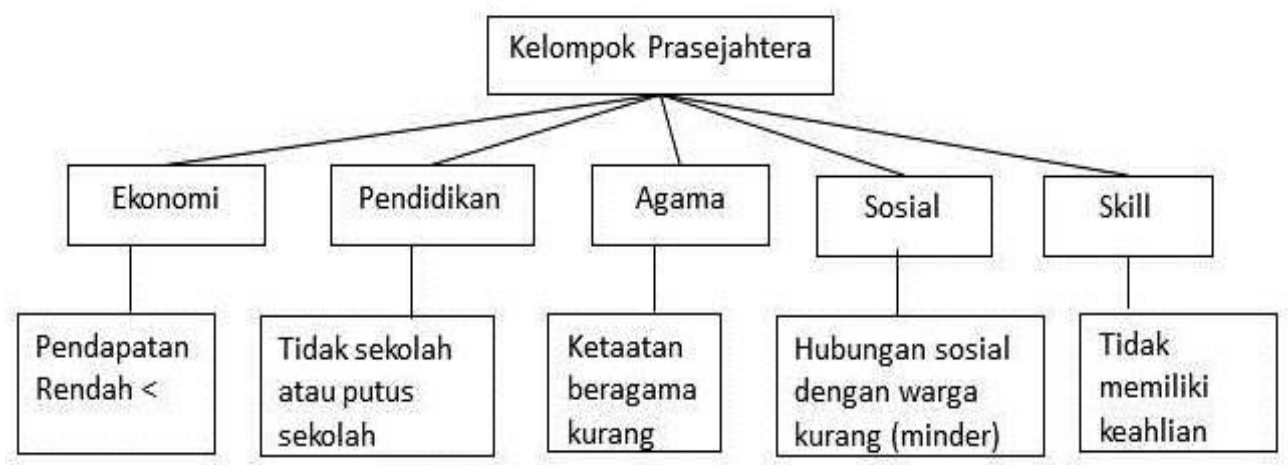

Gambar 4. Pohon masalah

Hasil FGD ini menjadi dasar untuk menganalisis kebutuhan dan menganalisis perencanaan pemecahan masalah. Beberapa pendapat dan masukan dari anggota diskusi ditampung dan dibahas untuk selanjutnya dipilih gagasan yang disepakati oleh anggota diskusi. Pada saat penetapan gagasan yang disepakati perlu juga memperhatikan sumber daya yang dimiliki oleh kelompok jamaah masjid sehingga dapat mendukung jalannya tindakan perubahan sosial masyarakat. Sumber daya yang ada dan dimiliki oleh anggota kelompok diantaranya yaitu sumber daya manusia yakni adanya Kyai masjid dengan keilmuan agama yang bagus, beberapa tokoh agama, pengusaha-pengusaha sukses, pegawai negeripegawai negeri, petani-petani kaya. Selain itu, masjid Nurul Hidayah juga memiliki sumber daya lingkungan yang sangat strategis untuk di 
kembangkan seperti lokasi yang cukup luas dengan luas tanah wakaf sekitar masjid kurang lebih 1 hektar, terdapat bangunan-bangunan pondok pesantren tanpa penghuni, dan terdapat beberapa gedung kosong, cocok untuk kegiatan perekonomian, dekat dengan jalan raya (50 m dari jalan Propinsi) dekat dengan Perguruan Tinggi dan Sekolah-sekolah.

Berdasarkan permasalahan yang telah dirumuskan dan dengan mempertimbangkan sumber daya yang dimiliki maka tahapan selanjutnya adalah penyusunan strategi gerakan untuk memecahkan masalah yang telah dirumuskan. Penyusunan strategi gerakan untuk pemecahan masalah yang Pengabdi gunakan adalah tehnik analisa LFA (Logical Framework Approach). Keuntungan menggunakan tehnik ini adalah melibatkan stakeholder sehingga dapat dianalisis asumsi dan resiko sesuai dengan keahliannya dan mewakili masing-masing kepentingan yang ada, melibatkan pemangku kepentingan dalam proses perencanaan dan monitoring, serta dapat digunakan secara dinamis dan efektif, dapat dipadukan antara implementsi, monitoring dan evaluasi. Keuntungan lain menggunakan tehnik analisis LFA adalah selain digunakan untuk perencanaan program sekaligus dapat digunakan sebagai alat untuk evaluasi program.

Pada proses pengevaluasian suatu program dengan menggunakan alat analisis LFA terdiri dari beberapa tahapan yang menjadi fokus dari penerapan Logical Framework Matrix yaitu memahami goal, Purpose, Outputs, dan activities. Logical Framework Matrix dapat dilihat pada Tabel 1.

Tabel 1. Logical Framework Matrix untuk siklus pertama

\begin{tabular}{|l|l|l|l|}
\hline $\begin{array}{c}\text { Narative } \\
\text { Summary }\end{array}$ & $\begin{array}{l}\text { Objectively Verifiable } \\
\text { Indicators (OVI) atau } \\
\text { Indikator Verifikasi } \\
\text { Sasaran Tujuan }\end{array}$ & $\begin{array}{c}\text { Means of } \\
\text { Verification } \\
\text { (MOV) atau } \\
\text { cara } \\
\text { verifikasi }\end{array}$ & $\begin{array}{c}\text { Important } \\
\text { Assumtions }\end{array}$ \\
\hline Goal & $\begin{array}{l}\text { Peserta mampu } \\
\text { menggali potensi, } \\
\text { memotivasi diri dan } \\
\text { mandiri }\end{array}$ & $\begin{array}{l}\text { Peserta } \\
\text { telah } \\
\text { mengikuti } \\
\text { kegiatan } \\
\text { FGD dengan } \\
\text { baik }\end{array}$ & \\
\hline Purpose & $\begin{array}{l}\text { Peserta memahami } \\
\text { pentingnya koperasi. }\end{array}$ & & \\
\hline Outputs & Peserta & & \\
\hline
\end{tabular}

$372 \mid$ JURNAL LISAN AL-HAL 


\begin{tabular}{|c|c|c|}
\hline & $\begin{array}{l}\text { mendapatkan } \\
\text { tambahan } \\
\text { pengetahuan dan } \\
\text { wawasan baru } \\
\text { tentang koperasi : } \\
\text { pengenalan, } \\
\text { manfaat, syarat } \\
\text { pendirian koperasi }\end{array}$ & \\
\hline Activities & $\begin{array}{l}\text { - Mengadakan } \\
\text { pelatihan koperasi } \\
\text { yang diadakan pada } \\
\text { bulan September } \\
2016 \\
\text { - Mengundang } 1 \\
\text { orang narasumber } \\
\text { pakar ekonomi- } \\
\text { koperasi } \\
\text { - Jumlah peserta } \\
\text { pelatihan } 60 \text { orang } \\
\text { - Peserta dari seluruh } \\
\text { jamaah dan } \\
\text { perangkat Desa }\end{array}$ & $\begin{array}{l}\text { Mengadakan } \\
\text { pelatihan } \\
\text { koperasi } \\
\text { dengan } \\
\text { mengundan } \\
\text { g } 60 \text { orang } \\
\text { dengan } \\
\text { asumsi } 60 \% \\
\text { kehadiran } \\
\text { peserta. }\end{array}$ \\
\hline
\end{tabular}

Sumber: Keerti, 2012

Hasil dari perencanaan selanjutnya di implementasikan dalam suatu kegiatan dalam hal ini kegiatan sosialisasi program Koperasi. Karena dengan koperasi maka besar kemungkinan kesejahteraan jamaahnya akan meningkat. Sebelum dibentuk koperasi, sebelumnya di lakukan pelatihan tentang koperasi bagi para jamaah masjid. Hal ini bertujuan untuk memberi gambaran dan wawasan terhadap jamaah tentang perkoperasian. Pelatihan dilaksanakan dengan menghadirkan narasumber (Bpk. Sumari, SE, MM) dari praktisi dan akademisi yang kompeten. Pelatihan dilaksanakan di serambi masjid pada tanggal 14 September 2016 dan dihadiri oleh 50 orang jamaah.

Keinginan dan kemauan keras untuk memakmurkan masjid menjadi latar belakang munculya ide-ide kreatif bagi para pengurus masjid (ta'mir) terutama dari kalangan muda. Diberikannya pelatihan tentang koperasi masjid ini merupakan langkah awal untuk membuka wawasan dan merubah pola pikir mereka sehingga memiliki semangat 
untuk mandiri. Upaya ini diharapkan mampu memberi pemahaman, pengertian sekaligus menstimulasi masyarakat dalam pengelolaan masjid yang lebih efektif dan berdaya.

Kegiatan evaluasi dilakukan setelah dilaksanakan aksi atau tindakan dengan maksud menglihat kembali sejauh mana program telah dilaksanakan dan tetap berada dalam jalur yang telah ditentukan serta melihat impresi dan efek yang dihasilkan. Sebenarnya evaluasi sudah termasuk dalam tehnik LFA pada bagian perencanaan. Setelah dilakukan evaluasi program pelatihan telah sesuai dengan perencanaan.

\section{Siklus Kedua}

Setelah siklus pertama selesai dijalankan dan berdasarkan hasil dari evaluasi dan refleksi maka kegiatan dilanjutkan dengan siklus yang kedua. Pada siklus kedua ini tahapannya meliputi perencanaan, aksi, evaluasi, dan refleksi. Kegiatan perencanaan pada siklus kedua ini meliputi kegiatan FGD antar anggota jamaah yang bertujuan untuk menyusun langkah atau strategi berikutnya. Musyawarah dilaksanakan tanggal 1 Oktober 2016. Hasil diskusi disepakati bahwa:

a. Pembentukan kepengurusan dan keanggotaan koperasi masjid. Susunan kepengurusan dan keanggotaan yang terbentuk dapat dilihat pada Lampiran 2.

b. Menentukan besaran simpanan pokok bagi setiap anggota dan disepakati setiap anggota mengeluarkan sebesar Rp. 200.000 sebagai simpanan pokok.

c. Menentukan jenis usaha yang akan dijalankan diantaranya yaitu usaha sembako, pulsa Token listrik, pulsa $\mathrm{Hp}$, alat tulis menulis, menyediakan buku TPQ-Qiraati dan layanan pembayaran PLN, pupuk dan obat pertanian.

Tabel 2. Logical Framework Matrix untuk siklus kedua

\begin{tabular}{|l|l|l|l|}
\hline Narative & $\begin{array}{c}\text { Objectively Verifiable } \\
\text { Indicators (OVI) atau } \\
\text { Indikator Verifikasi } \\
\text { Sasaran Tujuan }\end{array}$ & $\begin{array}{c}\text { Means of } \\
\text { Verification } \\
\text { (MOV) atau } \\
\text { cara verifikasi }\end{array}$ & $\begin{array}{c}\text { Important } \\
\text { Assumtions }\end{array}$ \\
\hline Goal & Peserta mandiri & $\begin{array}{l}\text { Peserta telah } \\
\text { mengikuti } \\
\text { kegiatan FGD } \\
\text { dengan baik }\end{array}$ & \\
\hline Purpose & Peserta berdaya & & \\
\hline
\end{tabular}

$374 \mid$ JURNAL LISAN AL-HAL 


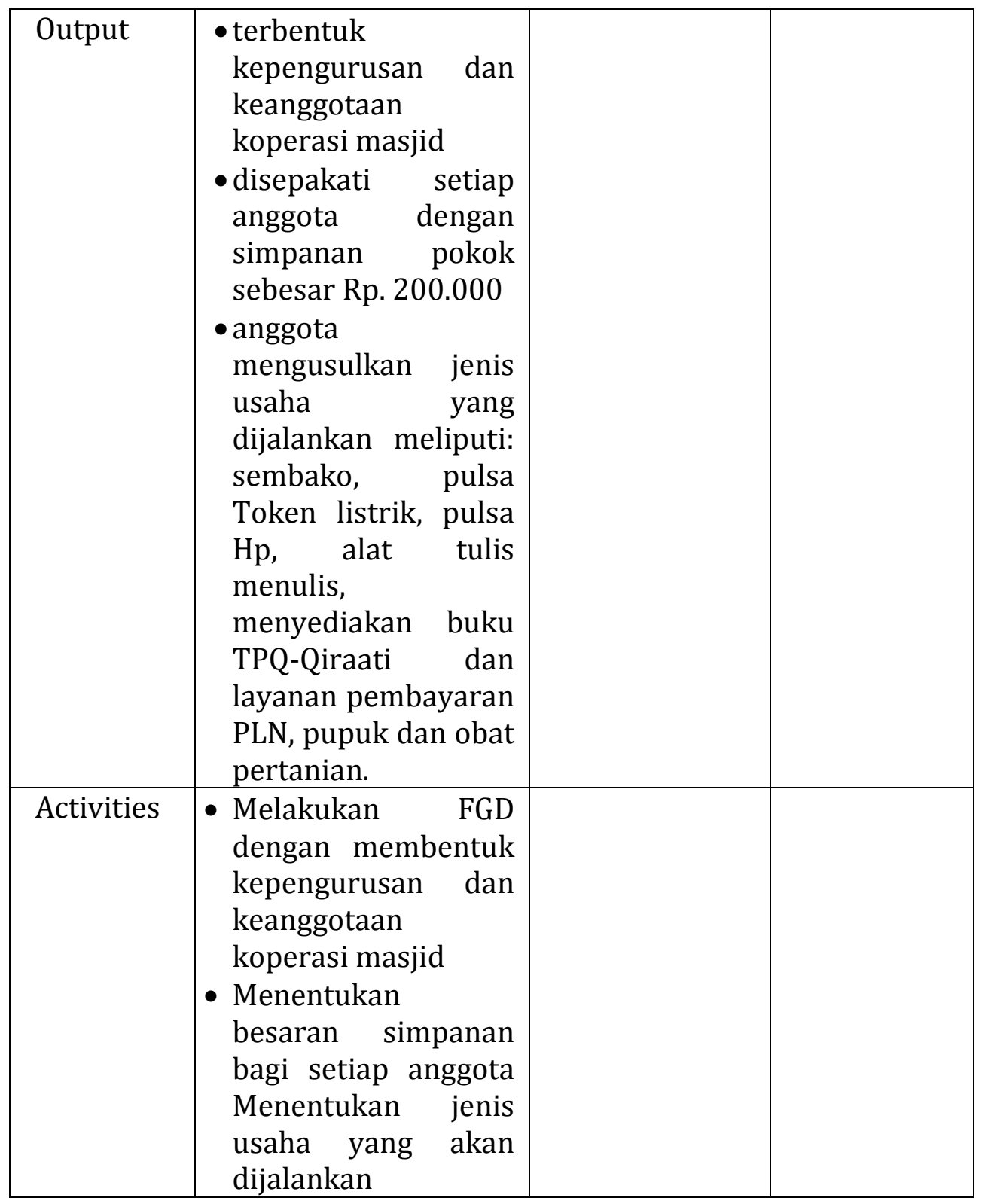

Sumber: Keerti, 2012

Pada tahap aksi, mulailah dibentuk dan dipersiapkan hal-hal yang dibutuhkan dalam pendirian koperasi mulai dari sarana dan prasarana. Salah satu kegiatan untuk itu adalah renovasi gedung kosong untuk dijadikan sebagai tempat penjualan beberapa produk usaha jamaah. Untuk sementara dana untuk renovasi tersebut berasal dari sumbangan anggota. 
Meskipun masih proses pembenahan dan renovasi bangunan, sebenarnya koperasi sudah mulai berjalan. Bidang usaha yang sudah berjalan adalah penyediaan buku-buku TPQ, Token listrik dan PLN. Pelanggan PLN yang membayar tagihan listriknya di koperasi mencapai kurang lebih 100-an orang.

Kegiatan ketiga dilakukan Evaluasi dan refleksi. Beberapa kegiatan masih belum bisa dilaksanakan karena masih terkendala ruang tempat koperasi dalam tahap rehab, akan tetapi rehabilitasi sudah mencapai 90\%, beberapa barang dagangan belum disediakan karena menunggu seselasi rehab bangunan. Mekipun demikian ada beberapa program yang sudah berjalan seperti pembayaran listrik PLN warga sekitar masjid kepada Koperasi masjid Nurul Hidayah. Mengingat program koperasi masjid merupakan jenis usaha yang membutuhkan proses yang sangat berlikuliku, sementara pengabdian ini berbatas waktu dan biaya, oleh karena itu diperlukan program lanjutan untuk mendampingi jamaah masjid kedepan.

\section{E. Diskusi Data}

Kegiatan perumusan masalah, perencanaan, tindakan/aksi pada siklus pertama semuanya melibatkan jamaah masjid Nurul hidayah dan stakeholder, sedangkan pengabdi sebagai fasilitator. Dalam setiap tahapannya para anggota dibimbing untuk menemukan dan merumuskan permasalahan mereka sendiri, mencari solusi dan membuat perencanaan program. Hingga disepakati program yang mereka butuhkan adalah koperasi. Hal ini untuk menjawab permasalahan utama yang telah mereka rumuskan yaitu tentang ekonomi jamaah masjid khususnya bagi jamaah dengan golongan prasejahtera. Pemberdayaan masyarakat berarti membantu masyarakat untuk memperkuat dan menciptakan daya/potensi (empowering) yang mereka miliki, mengembangkan (enabling) serta menjadikan mereka lebih mandiri². Dalam hal ini masjid memiliki arti yang sangat luas tidak hanya sebagai tempat sujud menyembah kepada Allah SWT. Masjid dijadikan sebagai pusat pembinaan dan kegiatan ummat. Pada masa itu masjid dijadikan sebagai tempat latihan perang, tempat pengobatan bagi tentara-tentara muslim, pengadilan, tempat menuntut ilmu, pusat dakwah, tempat pembinaan ummat, tempat kaderisasi umat islam dan kebudayaan ${ }^{3}$.

2 Tri Winarni, Memahami Pemberdayaan Masyarakat Desa Partisipatif dalam Orientasi Pembangunan Masyarakat Desa Menyongsong Abad 21: Menuju Pemberdayaan Pelayanan Masyarakat, (Aditya Media, Yogyakarta: 1998) tahun.

${ }^{3}$ Hamzah, A. Peran Masjid Dalam Meningkatkan Perekonomian Masyarakat. Tanpa

$376 \mid$ JURNAL LISAN AL-HAL 
Senada dengan Hamzah, Nazarudin Umar menyatakan bahwa Rosulullah tidak hanya menjadikan masjid sebagai tempat untuk pelaksanaan ibadah khusus, namun masjid juga dijadikan sebagai sarana melakukan pemberdayaan umat seperti tempat untuk pembinaan dan penyebaran agama Islam, tempat mengobati orang sakit, tempat mendamaikan orang-orang yang bertikai, tempat latihan perang, tempat menyampaikan pengumuman penting dan lain-lain ${ }^{4}$.

Jika disimpulkan setidaknya ada tiga peran dan fungsi yang diperankan oleh masjid; pertama peran tempat ubudiyah atau tempat peribadatan kaum muslimin, khususnya sholat lima waktu. Kedua tempat ijtimaiyah atau perkumpulan sosial-kemasyarakatan yakni berperan sebagai tempat memecahkan perkara sosial, berkumpul dan berdialog sehingga masalah yang terjadi di masyarakat dapat diselesaikan. Dan, ketiga tempat tarbiyah (pendidikan) yakni masjid menjadi tempat masyarakat mendapat pendidikan, pengajaran, bimbingan dan arahan dari para cerdik pandai.

Untuk menggapai maksud mulia diatas diperlukan pemahaman yang utuh mengenai fungsi masjid, sehingga terjadi perubahan pola pikir yang mengarah kepada kemandirian masyarakat. Proses kemandirian masyarakat dibutuhkan sebuah tahapan-tahapan hingga dapat menemukan hasilnya yang optimal dan menjadi berdaya. Konsep pemberdayaan sebagaimana diungkapan Prijono dan Pranarka mengatakan bahwa Proses pemberdayaan yang menekankan pada proses memberikan kemampuan kepada masyarakat agar menjadi berdaya, mendorong atau memotivasi individu agar mempunyai kemampuan atau keberdayaan untuk menentukan pilihan hidupnya. Dengan demikian segala sesuatu yang dikerjakannya merupakan hasil kesadaran dirinya, dilakukan dengan suka rela tanpa adanya tekanan dari pihak luar ${ }^{5}$. Pihak luar sebagai pendorong dan teman diskusi untuk menemukan terobosanterobosan baru yang dapat memperkuat nilai kemandirian masyarakat. Pemberdayaan haruslah ditujukan pada kelompok atau lapisan masyarakat yang tertinggal. Menurut Sumodiningrat, bahwa pemberdayaan masyarakat merupakan upaya untuk memandirikan masyarakat lewat perwujudan potensi kemampuan yang mereka miliki. Adapun pemberdayaan masyarakat senantiasa menyangkut dua kelompok

4 Tim Penyusun, Buku Panduan Kuliah Kerja Nyata Pembelajaran Pengabdian Masyarakat (KKN-PPM.), 2015.

5 A. M. W. Pranarka dan Vidhandika Moeljarto, Pemberdayaan Empowerment, dalam Onny S. Prijono dan A.M.W Pranarka (eds), Pemberdayaan: Konsep, Kebijakan dan Implementasi. 1996, 
yang saling terkait, yaitu masyarakat sebagai pihak yang diberdayakan dan pihak yang menaruh kepedulian sebagai pihak yang memberdayakan6, dalam hal ini peneliti atau pengabdi sebagai pihak pemberdaya dan masyarakat atau jamaah masjid sebagai pihak yang diberdayakan. Jamaah masjid yang menjadi titik tekan dalam pemberdayaan ini lebih diarahkan kepada warga prasejahtera (miskin), dimana mereka tidak sanggup untuk memenuhi kebutuhan dasar hidupnya. Kemiskinan sebagaimana diungkapkan Zastrow adalah bahwa penyebab kemiskinan berkaitan dengan masalah-masalah sosial seperti tingkat pengangguran yang tinggi, kesehatan yang rendah, dan pendidikan rendah?.

Kaitan kemiskinan ini Chamber dalam Sutrisno mengatakan bahwa ada lima ketidakberuntungan yang melingkari kehidupan orang miskin, yaitu kemiskinan itu sendiri, fisik yang lemah, kerentanan, keterisolasian dan ketidakberdayaaan. Kemiskinan yang bersifat multidimensional ini penanganannya tidak hanya berorientasi pada masalah dan reaktif. Melainkan membutuhkan penanganan terpadu pada berbagai determinan yang mempengaruhinya. Oleh karena itu paradigma penanganan masalah harus mulai dirubah dari bantuan sosial yang bersifat charitas menjadi bantuan pemberdayaan.

Selanjutnya pemberdayaan masjid melalui koperasi memiliki berbagai kelebihan. Hal ini seperti yang dikatakan Hendrojogi (2004), bahwa pada dasarnya koperasi itu mengandung dua unsur, yaitu unsur ekonomi dan unsur sosial. unsur ekonomi mempunyai tujuan ekonomi dengan kata lain koperasi harus bekerja berdasarkan motif ekonomi, sedangkan bagian-bagian yang saling berkaitan tersebut merupakan unsur-unsur ekonomi, seperti digunakan sistem pembukuan yang baku, diadakan pemeriksaan, adanya cadangan dan lain-lain ${ }^{8}$.

Sementara unsur sosial menunjukkan kedudukannya ia sebagai anggota dalam organisasi, mempunyai hubungan antar sesama anggota dan hubungan anggota dengan pengurus. Disamping itu pula unsur sosial dapat ditemukan tentang pembagian sisa hasil usaha dan menolong dirinya sendiri serta akan menimbulkan persaudaraan dan kebersamaan. Dengan demikian dengan berkoperasi jamaah masjid memiliki keuntungan ganda yanitu peningkatan kesejahteraan ekonomi dan kedua

6 Gunawan Sumodiningrat, Pemberdayaan Masyarakat dan Jaringan Pengaman Sosial, (Jakarta: PT Gramedia Pustaka Utama: 1999)

7 Charles. H Zastrow. The Practice of Social Work, Sith Edition. Pacific Grove: Brooks/Cole Publishing Company. An International Thomson Publishing Company. 1999.

8 Hendrojogi,. Koperasi: azas-azas. Teori dan praktek, koperasi, cetakan Pertama, (PT Rineka Cipta, Jakarta. 2002)

$378 \mid$ JURNAL LISAN AL-HAL 
mempunyai ikatan emosional yang sama dengan sesama jamaah masjid.

Pemberdayaan yang dilakukan kepada jamaah masjid Nurul Hidayah ini dapat menggali potensi yang mereka miliki baik potensi SDA maupun SDM nya. Setelah menggali potensi selanjutnya mendorong dan memotivasi jamaah untuk mengembangkan potensi tersebut sehingga mereka menjadi mandiri. Keberhasilan pemberdayaan dapat dilihat dari antusiasnya mereka dalam mengikuti setiap tahap kegiatan mulai dari perumusan masalah, perencanaan program, pelaksanaan program hingga kegiatan evaluasi dan refleksi. Antusias para jamaah dapat dilihat dengan banyaknya masukan, gagasan, yang muncul dari jamaah.

Pelatihan koperasi yang telah dilaksanakan di masjid Nurul Hidayah telah membuka wawasan baru dan merubah pola pikir jamaah masjid menjadi lebih mengerti betapa penting dan besar manfaat berkoperasi dan selanjutnya mereka berkeinginan untuk mendirikan koperasi sendiri sebagai sarana untuk meningkatkan dan membantu jamaah prasejahtera untuk menjadi sejahtera. Pasal 3 UU No.25/1992 menyebutkan bahwa koperasi memiliki tujuan memajukan kesejahteraan anggota pada khususnya dan masyarakat pada umumnya, serta ikut membangun tatanan perekonomian nasional dalam rangka mewujudkan masyarakat yang maju, adil dan makmur berlandaskan Pancasila dan UUD 1945. Dalam menjalankan koperasi menurut Hendrojogi anggota akan mendapatkan dua manfaat sekaligus yakni manfaat koperasi di secara ekonomi dan manfaat koperasi disecara sosial. Manfaat koperasi di secara ekonomi akan meningkatkan penghasilan anggota-anggotanya, dapat menawarkan barang dan jasa dengan harga yang lebih murah, dapat menumbuhkan motif berusaha yang berperikemanusiaan, menumbuhkan sikap jujur dan keterbukaan dalam pengelolaan koperasi, melatih masyarakat untuk menggunakan pendapatannya secara lebih efektif dan membiasakan untuk hidup lebih hemat. Sementara manfaat koperasi secara sosial di bidang sosial dapat mendorong terwujudnya kehidupan masyarakat damai dan tenteram, mendorong terwujudnya aturan yang manusiawi yang dibangun tidak di atas hubungan-hubungan kebendaan tetapi di atas rasa kekeluargaan dan Mendidik anggota-anggotanya untuk memiliki semangat kerja sama dan semangat kekeluargaan.

Hasil evaluasi dan refleksi pada siklus pertama, secara umum sudah berjalan sesuai dengan apa yang telah direncanakan selanjutnya para anggota jamaah menginginkan untuk mendirikan koperasi masjid sehingga program pengabdian ini kami lanjutkan kedalam siklus kedua. Pada siklus kedua ini jamaah merencanakan untuk mendirikan koperasi, untuk itu segala persyaratan yang dibutuhkan dilengkapi diantaranya 
yaitu pembentukan kepengurusan dan keanggotaan, menentukan bidang usaha: usaha sembako, pulsa Token listrik, pulsa Hp, alat tulis menulis, menyediakan buku TPQ-Qiraati dan layanan pembayaran PLN, pupuk dan obat pertanian. Namun karena beberapa kendala sehingga yang bisa dijalankan saat ini adalah penyediaan buku-buku TPQ, Token listrik dan PLN sedangkan jamaah yang sudah mendaftar menjadi anggota sebanyak 35 orang termasuk dari golongan sejahtera III plus, sejahtera III, sejahtera II, sejahtera I dan tentunya golongan prasejahtera. Pembentukan Koperasi masjid Nurul Hidayah sudah memenui beberapa pasal yang ada. Berdasarkan UU No.25/1992 tentang perkoperasian, syarat membentuk koperasi pasal 6 ayat 1 berbunyi bahwa koperasi primer dibentuk oleh sekurang-kurangnya 20 (duapuluh) orang. Pasal 7 ayat 1 menyebutkan bahwa pembentukan Koperasi sebagaimana dimaksud dalam Pasal 6 dilakukan dengan akta pendirian yang memuat Anggaran Dasar dan ayat 2 berbunyi koperasi mempunyai tempat kedudukan dalam wilayah negara Republik Indonesia.

Hasil evaluasi pada siklus kedua ini merujuk pada kendala-kendala yang menyebabkan program belum berjalan secara makasimal. Setelah dianalisa kendala berupa kurangnya modal dan tenaga pengurus hal ini karena kesibukan dari masing-masing pengurus sehingga koperasi belum bisa maksimal menjalankan tupoksinya.

Tentunya dalam melaksanakan koperasi yang profesional ini tidak semudah membalikkan telapak tangan, diperlukan semangat yang tinggi, ulet, tangguh yang harus dimiliki oleh anggota koperasi terutama bagi pengurusnya. Sampai saat ini, koperasi jamaah masjid Nurul Hidayah dalam tahap renovasi bangunan yang direncanakan sebagai tempat kantor dan sekaligus pusat pertokoan.

Pembentukan koperasi masjid yang dilakukan oleh jamaah masjid Nurul Hidayah ini merupakan langkah maju dan langkah awal untuk meningkatkan perekonomian jamaah masjid. Selanjutnya perlu dilakukan pendampingan menejerial koperasi sehingga koperasi dapat berjalan sesuai dengan perannya dan tentunya kesejahteraan dapat dirasakan oleh semua anggota. Karena koperasi yang dijalankan berbasis agama, maka praktik koperasi haruslah tidak bertentangan dengan prinsip-prinsip syari'ah, maka diperlukan adanya transaksi-transaksi muamalah yang menjadi pijakan. Dilihat dari usaha yang dijalankan secara bersama-sama koperasi identik dengan persekutuan (syirkah) dimana didalam Islam sendiri dibolehkan9 ${ }^{9}$. Oleh karena itu segala bentuk praktik koperasi ini

9 Burhanudin Dwi Rokhmatun, Profesi Kearsipan Memahami Profesi Kearsipan, 
akan didasarkan pada prinsip-prinsip syirkah itu sendiri, sehingga menjadi jelasa kehalalannya.

\section{F. Simpulan}

Simpulan yang dapat diambil dari program pengabdian pada masyarakat jamaah masjid Nurul Hidayah ini adalah pertama, bentuk pemberdayaan jamaah berupa program peningkatan perekonomian dalam bentuk pelatihan dan pendirian koperasi. Ke dua, Pelaksanaan program pemberdayaan jamaah masjid Nurul Hidayah dalam bentuk pelatihan dan pendirian koperasi berjalan dengan cukup lancar. Sudah terbentuk kepengurusan dan keanggotaan dengan bidang usaha yang dijalankan meliputi usaha penyediaan buku-buku Qiraati, pulsa Token listrik dan PLN. Namun beberapa belum terlaksana karena terbatas modal dan waktu. Ke tiga, Hasil dari program pemberdayaan jamaah masjid Nurul Hidayah sudah mampu menggali, mendorong dan memotivasi serta menjadikan jamaah prasejahtera khususnya lebih mandiri dan percaya diri.

\section{DAFTAR PUSTAKA}

Burhanuddin, 2013. Koperasi Syariah dan Pengaturannya di Indonesia, Malang: UIN MALIKI Press.

Dwi Rokhmatun, Burhanudin. Profesi Kearsipan Memahami Profesi Kearsipan, Karakteristik \& Syarat, Ketrampilan \& Pengetahuan, Kompetensi, dan Kode Etik Arsiparis. Yogyakarta: Panduan, 2013.

Hamzah, A. Peran Masjid Dalam Meningkatkan Perekonomian Masyarakat. Tanpa tahun.

Hamzah, A. Tanpa tahun. Peran Masjid Dalam Meningkatkan Perekonomian Masyarakat.

Hendrojogi, 2004, Koperasi: Asas-asas, Teori, dan Praktik, Jakarta: Rajawali Press.

Hendrojogi,. Koperasi: azas-azas. Teori dan praktek, koperasi, cetakan Pertama, PT Rineka Cipta, Jakarta. 2002.

http://www.worldbank.org/in/country/indonesia/news/all?topic_exact= Poverty Pada tanggal 18 September 2016.

Karakteristik \& Syarat, Ketrampilan \& Pengetahuan, Kompetensi, dan Kode Etik Arsiparis (Yogyakarta: Panduan, 2013)

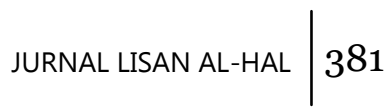


https://mtsfalakhiyah.wordpress.com/2011/01/07/lembaga-tamirmasjid-indonesia-htmi/

http://ceritasoleh.blogspot.co.id/2012/03/hasil-riset-899-persen-masjidsepi.html

Ismail Ruslan, pemberdayaan ekonomi masyarakat berbasis masjid di Pontianak. Volume 2 Nomor 1 Maret 2012, Jurnal Khatulistiwa Journal Of Islamic Studies.

Kusnadi. 2006, Filosofi Pemberdayaan Masyarakat Pesisir, Penerbit Humaniora, Bandung.

Pranarka, A. M. W. dan Moeljarto, Vidhandika. Pemberdayaan Empowerment, dalam Onny S. Prijono dan A.M.W Pranarka (eds), Pemberdayaan: Konsep, Kebijakan dan Implementasi. 1996,

Sugarto, Edi. 2005. Membangun Masyarakat Memberdayakan Rakyat: Kajian Strategis Pembangunan Kesejahteraan Sosial dan Pekerjaan Sosial, Bandung: Refika Aditama.

Sumodiningrat, Gunawan. Pemberdayaan Masyarakat dan Jaringan Pengaman Sosial, Jakarta: PT Gramedia Pustaka Utama: 1999.

Tim Penyusun, 2015. Buku Panduan Kuliah Kerja Nyata Pembelajaran Pengabdian Masyarakat (KKN-PPM.)

Winarni, Tri, Memahami Pemberdayaan Masyarakat Desa Partisipatif dalam Orientasi Pembangunan Masyarakat Desa Menyongsong Abad 21: Menuju Pemberdayaan Pelayanan Masyarakat, Aditya Media, Yogyakarta: 1998.

Zastrow, Charles. H. The Practice Of Social Work, Sith Edition. Pacific Grove: Brooks/Cole Publishing Company. An International Thomson Publishing Company. 1999.

$382 \mid$ JURNAL LISAN AL-HAL 